\title{
The BioValley Life Sciences Week, Where Biotech and MedTech Met
}

\author{
Christian Suter* and Fritz R. Bühler
}

\begin{abstract}
For the third time the BioValley Life Sciences Week took place from October 13 to 22, 2004 in the French, German, and Swiss centers of the BioValley Life Sciences Network. Events included a 'Science et Cité' evening in Lörrach about new concepts in cancer management, the Business Platform in Freiburg where Biotech met Pharma, the 'Fête de la Science' in Strasbourg highlighting the challenges for XXIst century research, the BioValley Annual Conference in Colmar where the BioValley profile was discussed, the University Day in Strasbourg presenting the European Pharmacopoeia and looking at Drug Discovery 2004 and a sequence of events in Basel which were attended by more than 1500 persons. Events in Basel included the Science Day on systems biology and nanosciences, the Connect Day which was devoted to Partnering and Financing, the Medtech Day where this less well known but very important industry showed its cutting edge technologies, and finally the BioValley College Day attracting several hundred students from the neighboring high schools of the three countries. The BioValley Life Sciences Week has established itself firmly in the calendar of the region and will be organized again in the fall of 2005.
\end{abstract}

Keywords: BioValley Life Sciences Week · Business Platform · European Pharmacopoeia · Medical technology · Nanosciences · Systems biology

With successful meetings in the past two years the organizers had assembled a high-quality and greatly enhanced program for this year's BioValley Life Sciences Week, which took place from October 13 to 22 in the trinational region.

The week turned out to be a lively networking event, and a great occasion to learn more about this new and rapidly growing industry and its most prominent activities in the BioValley.

The Basel series of four days began Tuesday, 19. October, with a Science Day

${ }^{*}$ Correspondence: Dr. C. Suter

BioValley Basel

Blumenrain 23

$\mathrm{CH}-4051$ Basel

Tel.: +41613024947

Fax: +41612657655

E-Mail: christian.suter@suterscience.ch devoted to systems biology and nanotechnology.

\section{The Strategic Network in Systems Biology}

In his opening address, Mark Fishman, Head of Pharmaceutical Research of Novartis, spoke about 'A New Grammar for Drug Discovery'. A human being may be coded by about 20'000 genes, a large number. Functionality is, however, composed of only a few hundred pathways. These offer new opportunities for biomedical research and may, eventually, lead to a whole new drug repertoire.

How researchers in big pharma apply systems biology to the identification of new drug targets was shown by Hanno Langen of F. Hoffmann-LaRoche AG (the Event Partner of Science Day). He pointed to the amazing speed and efficiency of currently applied experimental techniques, e.g. mass spectroscopy.

Looking at systems comprehensively and trying to gain insight into function was the theme of the contribution of Rudolf Aebersold of the ETH Institute for Systems Biology. And he was able to show that taking a systematic approach does not necessarily mean a huge group of people: His investigation of new phosphatase binding networks was performed by just half a dozen researchers at the Seattle location.

An array of faculty speakers of the Biocenter, the Departement für Klinisch-Biologische Wissenschaften and the Friedrich Miescher Institute then showed that the Basel Network in cell biology expertly covers all major aspects from molecular biology to systems biology. The new Basel ETH Center in Systems Biology will find a prepared network to interface with.

\section{Nanotechnology in Life Sciences and Opportunities for the Basel Area}

Plenary speakers Dario Anselmetti of the University of Bielefeld, Christoph Gerber of the University of Basel/IBM Research Lab and Andreas Engel of the Biocenter presented applications of nanobiophysics and nanomechanics allowing the direct observation of proteins relevant to major human diseases and of membrane proteins in general. Further exploits in nanotechniques and exciting perspectives in nanomedicine were discussed by their colleagues of the NCCR Nanoscale Science Basel.

Hans-Joachim Güntherodt of the University of Basel and NFS Nanosciences took an audience of more than 300 persons 
through an elaborate show of pure and applied science to provide insight into the amazing world of nanoscience, and colleagues of the University and of Roche presented current uses of the technology in pharma research and prospective applications in medtech, e.g. employing a system for minimally invasive diagnosis of diseased states of joint cartilage. Nanotechnologies offer great opportunities to small enterprises with innovative techniques as shown in presentations of three CEOs of newly founded enterprises that sell their products worldwide.

\section{BioValley Connect Day - The Regional Partnering and Finance Conference}

An impressive mix of courageous entrepreneurs, astute financiers and business representatives of large and medium size pharma firms met on Wednesday, 20 October, for the Connect Day. Well over 200 persons followed company presentations given by 18 CEOs or CFOs of biotech companies in this largest regional gathering of the biotech, pharma and venture capital industries, the latter represented by 15 Central European risk capital organizations. The quality of the presenting firms was very high. Quite a number of them are active in the fields of immunology/antibacterials and cancer, some with products in clinical development phase II and III.

Seeking venture capital is one purpose of speaking at this networking meeting, prospecting for partnerships with pharma and with suitable biotech firms another. Deals with pharma may include straightforward license agreements for advanced compounds or a combination of joint discovery research and product license deals. Not that many pure platform technology companies were present this time.

As risk capital continues to be hard to find, partnerships with pharma are sought vigorously. Collaborations among biotech firms are increasing as well, and we noted a very recent joining of forces of biotechs in the merger of MyoContract with Graffinity to form Santhera Pharmaceuticals.

Victor Hartmann of Novartis Pharma Event Partner of the day jointly with the Novartis Venture Fund - in his plenary lecture pointed out the importance of licensing in for building a convincing portfolio and drug pipeline. A clear strategy for acquiring products and research services was put in place to facilitate contacts with the smaller biotech companies. Serious meetings of biotech officers with representatives of the more than two dozen financial and pharma firms took place throughout the day and into the social gathering in the evening. Compared with a year ago Connect has become a more serious and business-focused partnering conference where hundreds of ideas and thousands of business cards are exchanged.

\section{BioValley MedTech Day}

New in the program of the Week was the MedTech Day, created in order to provide an opportunity for University researchers to meet with the medical technology industry, which is so well established in the BioValley. The day was partnered with the Basellandschaftliche Kantonalbank and Ernst\&Young. The morning provided good insight into collaborative projects of universities with technical universities and of these universities with the industries: regional and European research networks abound, especially in the field of biomechanics.

New business opportunities and the efforts for continuous renewal of product lines were discussed by representatives of prosthetics and diagnostics firms.

We saw how market leaders compete, strive for market share, consolidate, or also exit specific market segments. And we were impressed by the strong global position of the market leaders headquartered in the region. From Ernst\&Young and KTI we learned that markets are growing, are underused and thereby offer great opportunities for companies with innovative offerings.

The concluding panel discussion underlined the special situation we have in our region: the global players, the pivotal research institutions including nanotechnology and systems biology. We also have industries in transition, e.g. the watchmaking industry, with technical skills that could become available for the Medtech build-up. Clearly a convergence of biology, nanoscience and medical technology is in the making, adding to, and complementing, the new treatment concepts in pharmaceutical science.

\section{The BioValley College Day and Network}

Founded just a year ago, this new collaborative network of some twenty colleges - eight from Alsace, four from Southern Germany and another eight from Northwestern Switzerland - including more than 40 teachers and principals, met on October 22 in the morning for a teaching program with more than 300 college students representing these schools. There were three superb presentations by college students discussing their research projects and of three university students reporting on their theses. The latter were pure role models for the college students. The crowning event of the College Day was a critical and charming television interview with Jeff Schatz, Swiss Science and Technology Council. Professor Schatz had just the preceding evening received the Goldig Läggerli award, the 'Oscar' of BioValley Basel.

Received: October 26, 2004 